\title{
Detection and Assay of Mitochondrial Aspartate Aminotransferase in Serum
}

\author{
By T. R. C. Boyde \\ Department of Clinical Biochemistry University of Nesvcastle upon Tyne
}

(Eingegangen am 30. April 1968)

$A$ sensitive and specific clectrophoretic procedure is described for the assay of cationic aspartate aminotransferase in human serum.

$0.1 \mathrm{mU}$ of enzymic activity can be detected with easc.

Normal scrum contnins approximatcly $3 \mathrm{U} / l$ cationic isocnzyme. This can be identified uncquivocally by the new procedure, and confirmatory experiments are described.

Für die Bestimmung der kationischen Aspartattransaminase in Serum des Menschen wird cine empfindliche und spezifische elektrophoretische Methode beschrieben. 0,1 $\mathrm{mU}$ können cinfach nachgewiesen werden. Normalscrum enthïlt etwa $3 \mathrm{U} / /$ kationisches Isocinzym. Dieses kann mit der angegebenen Methode cindeutig identifizicrt werden. Versuche, dic das bestïtigen, werden beschricben.

Aspartate aminotransfcrase (L-aspartate: 2-oxoglutarate aminotransferase, EC 2.6.1.1) comprises two isoenzymes. One is anionic, is associated with the soluble fraction of the cell and ordinarily forms the bulk of the scrum activity. The other is cationic, and is associated with the mitochondria (1-7). Each may in turn be subdivisiblc (8-10), but it is unlikely that this will influcnce the present results.

In suitable conditions of electrophoresis, the cationic isoenzyme is bound to $\alpha_{2}$-macroglobulin, and migrates as a compact and sharply defined zone to a distinctive position, "zonc II" (7). For present purposes, this phenomenon is uscful in that the activity is concentrated into a small area, making detection more sensitive. The physical basis and the specificity of this procedure have been established by extensive expcriments $(7,12,13)$ but it was not suspected that cationic aspartate aminotransferase might be present in normal scrum.

In developing a scrum assay, scnsitivity was further increased by altcring the substrate concentrations towards the optima for cationic isoenzymc (11), and by reducing the amount of $\mathrm{NADH}$ used. As a result zonc II was now detected in normal serum specimens. This paper describes the assay procedure and also the cxpcriments undertaken to confirm the nature of the observed activity.

\section{Materials and Reagents}

Malate dehydrogenase, NADH, and 2-oxoglutaric acid were purchased from Boehringer Corporation Ltd. Mnlate dehydrogenase was in the form of a suspension in $2.0 \mathrm{M}$ ammonium sulphate. The salt was removed by dialysing small portions, enough for one week's work, against at least 500 volumes of $0.02 \mathrm{M}$ Trisacctate buffer overnight at $4^{\circ}$. The volume doubled during this process. 2-oxoglutarate was prepared as a $100 \mathrm{~mm}$ solution, $\mathrm{pH} 7.4$, by titrating the acid with $2.0 \mathrm{M} \mathrm{NaOH}$, using a $\mathrm{pH}$ metcr, and was stored at $4^{\circ}$ over chloroform.

I-aspartic acid was purchased from Koch-Light Laboratories. A $1.0 \mathrm{M}$ stock solution $\mathrm{pH} 7.4$ was prepared as for 2-oxoglutarate, and was stored at $4^{\circ}$ over chloroform. Tris was purchased from Sigma Chemical Co. ('Trizma base'). Acetic acid, boric acid, sodium hydroxide, and ammonium persulphate were obtained from British Drug Houses Itd., (' $\Lambda$ nalaR' grade).

Tris-acotate buffer

$\Lambda$ stock $0.2 \mathrm{M}$ solution was madc by weighing out 0.165 molc acetis acid, diluting this with water, dissolving in it 0.2 mole
'Tris' and making up to 1 \%. This gave a pIt of 7.4 at the dilutions used.

\section{Borale buffor}

$\Lambda$ stock $0.5 \mathrm{M}$ solution was prepared by dissolving 1.0 mole $(61.8 \mathrm{~g})$ $\mathrm{H}_{3} \mathrm{BO}_{3}$ in $800 \mathrm{~m} /$ water contnining 0.17 mole NaOll, heating to dissolvc, and, when cool, diluting with water to $2.0 \%$. This kept indefinitely in a polythene containcr. Dilution of $100 \mathrm{~m} /$ to $2.0 /$ gave the $25 \mathrm{~mm}$ buffer, pH 8.4 , used for clectrophoresis.

Acrylamide and $\mathrm{N}, \mathrm{N}^{\prime}$-methylenc-bis-acrylamide were supplied by Koch-J_ight Inaboratorics. 'The dry powders were weighed out in 25:5 ratio, thoroughly mixed in a pestlc and mortar, and stored in bulk in this form.

$N, N, N^{\prime}, N^{\prime}-$ Tetramethylethylencdiamine was supplicd by EnstnuanKodak. $\Lambda$ garose was purchased from l-Iughes and I-Jughes (Enrymes) Itd. $\Lambda 2 \%$ solution in water was prepared by henting on a boiling water bath, and was kept in a screweapped jar.

\section{Methods}

Assay of total aspartatc aminotransfcrasc

The procedure (11) was modificd from that of KARMIIN (14) in that tris-acetate buffer was substituted for phosphate, and the L-aspartate concentration increased from $33 \mathrm{~mm}$ to $100 \mathrm{~mm}$. This resulted in rates $25 \%$ greater than in the original procedurc. Temperature was controlled at $25^{\circ}$. For the purposes of this paper, one unit (U) is the quantity of enzync which is able to convert $1 \mu$ mole of aspartate to oxaloacetate per min under the specified assay conditions (11).

Scmiquantitative assay of cationic isocn\%ymc in scrum Apparatus

The electrophoresis tray was specially constructed of "Perspex" and had internal dimensions: - length $15.0 \mathrm{~cm}$ (in the axis of protein migration), width $20.0 \mathrm{~cm}$. depth $0.75 \mathrm{~cm}$. The cover was made of "Perspex" $0.3 \mathrm{~cm}$ thick, $17.0 \mathrm{~cm}$ long and $22 \mathrm{~cm}$ wicle, and to this was glued an inner zone $0.15 \mathrm{~cm}$ decp, $14.9 \mathrm{~cm}$ long and $19.9 \mathrm{~cm}$ wide, fitting snugly into the well of the tray, and reducing the thickness of the gcl itsclf to $0.6 \mathrm{~cm}$. Inscrtion slot formcrs, 20 in number, were glued to this inner zonc in a single row perpendicular to the dircetion of protcin migration and $5.0 \mathrm{~cm}$ from one end. Each slot former was $0.15 \mathrm{~cm}$ thick (in the direction of protcin migration), $0.6 \mathrm{~cm}$ wide and $0.5 \mathrm{~cm} \mathrm{decp}$, projecting down into the gel.

\section{Electrophoresis procedure}

To cast a gel, $9.0 \mathrm{~g}$ of the acrylamicle/hisncrylamide mixture plus $200 \mathrm{mg}$ ammonium persulphate were dissolved in water to a final volume of $200 \mathrm{~m} /$. Immedintcly before use, $0.2 \mathrm{~m} / \mathrm{tetrn-}$ methylethylenedinmine was added, the whole thoroughly mixed and pourcd catefully into the tray, set on a level surface. 'I'he cover was now lowered gently into place, taking grent care to extrude air bubbles, and the slight excess of solution squeezed out by placing weights of about $1 \mathrm{~kg}$ on top. After one hour (to ensure 
completion of the polymerisation reaction) the cover was gently levercd off.

Catalysts, and any unchanged monomer, were removed from the gel by dialysis. The gel was freed from its tray by running a spatula round the periphery and squirting a little water underneath, and was slid out into a larger; deeper tray of $1 . l$ 'capacity. The gels were too weak and slippery to handle.

Dialysis was with three changes of the electrophoretic buffer, using about $700 \mathrm{~m} l$ each time, leaving this in contact for 2 hours with occasional agitation, and then removing the buffer by aspiration. When dialysis was complete, the gel was returned to its original tray, again by sliding it from one receptacle to the other. With this relatively brief period of dialysis there was no appreciable swelling of the gel.

Excess solution was swept off the surface of the gel with a plastic batten (filter paper tended to adhere to the surface) and aspirated from the sample slots with a Pasteur pipette.

The samples were applied in agarose gel to prevent electrodecantation. A PASTEUR pipette was prepared with a stem of approximately $1.5 \mathrm{~mm}$ diameter having a tip of approximately $0.3 \mathrm{~mm}$ diameter, and marks were made indicating volumes of $15 \mu l$ and $75 \mu \mathrm{l}$. A small portion of the $2 \%$ agarose solution was melted down in a boiling water-bath. Molten agarose was drawn up to the first mark on the PASTEUR pipette, and, after wiping the pipette, the sample was drawn up to the second mark. The contents of the pipette were then expelled into one of the depressions of an immunological dimple tray, mixed rapidly by drawing up and expelling several times, and then transferred to the sample slot, which was filled flush with the surface of the gel. The pipette was rinsed with warm $\left(40^{\circ}\right)$ saline and then with boiling water before repeating the cycle of operations with subsequent samples.

Agarose tending to set in the pipette was removed by rinsing in boiling water. Such blockages occurred most frequently in the narrow outlet of the pipette, but this feature was highly desirable because it helped in controlling the column of fluid in the stem of the pipette and in delivery to the sample slot. Bubbles were carefully avoided.

The agarose, when first taken up into the pipette, was of course at about $100^{\circ}$, but cooled rapidly, so that denaturation of protein in the sample was considered unlikely.

Electrophoresis was carried out in the horizontal position, in a cold room at $4^{\circ}$, overnight $(16 \mathrm{~h})$ at $2.0 \mathrm{~V} / \mathrm{cm}$, the tray resting on the edges of the buffer tanks and making contact through buffersoaked cloth wicks, $10 \mathrm{~cm}$ by $20 \mathrm{~cm}$. The buffer tanks were large ( 2 l capacity) and over $20 \mathrm{~cm}$ wide since electrophoresis was in the short $(15.0 \mathrm{~cm})$ axis of the gel. The tanks used were fitted with platinum electrodes. If runs were being done on successive nights, it was possible to economise in the use of buffer by reversing the polarity of the electrodes each night, but buffer was never kept longer than 4 days. A $120 \mathrm{~V}$ dry battery was used to provide the potential for electrophoresis, giving $20 \mathrm{~V}$ measured at points $10 \mathrm{~cm}$ apart on the gel surface. The commonest difficulty experienced was too low conductivity in the cloth wicks, and it was found desirable to use at least 6 layers of cotton shirt material. The central portion of the gel was covered with polythene film to prevent evaporation.

\section{Detection and Assay Procedure}

When electrophoresis was complete, the gel was placed in an incubator at $37^{\circ}$ whilst other preparations were made.

A portion of the stock $2 \%$ agarose solution was melted down in a boiling water-bath, then briefly cooled in a water-bath at about $40^{\circ}$. Meanwhile, in another test-tube, a mixture was made up containing aminotransferase substrates, malate dehydrogenase, $\mathrm{NADH}$ and buffer. This was warmed to $40^{\circ}$ in the same waterbath as above. After $20 \mathrm{~min}$. in the $37^{\circ}$ incubator the gel was placed on an absolutely level surface, and one corner covered with a square piece of "Perspex" 2.5 by 2.5 by $0.6 \mathrm{~cm}$, to provide a control area of gel free from $\mathrm{NADH}$ fluorescence. The agarose solution and substrate solution were mixed, the mixture poured over the surface of the gel, and quickly spread with a glass rod. If
Composition of Detection Mixture

\begin{tabular}{|c|c|c|c|}
\hline $\begin{array}{c}\text { Reagent } \\
\cdot \\
\cdot \quad \cdot\end{array}$ & $\begin{array}{l}\text { Quantity } \\
\text {. }\end{array}$ & $\begin{array}{l}\text { Initial } \\
\text { concn. in } \\
\text { agarose } \\
\text { soln. }\end{array}$ & $\begin{array}{l}\text { Final concn. } \\
\text { in gel } \\
\text { (assuming } \\
\text { equilibrium } \\
\text { diffusion } \\
\text { where } \\
\text { appropriate) }\end{array}$ \\
\hline $\begin{array}{l}\text { Agarose } 2 \% \\
\text { L-aspartate } \\
\text { 2-oxoglutarate } \\
\text { Tris-acetate buffer } \\
\text { MDH (Dialysed) } \\
\text { NADH }\end{array}$ & $\begin{array}{l}4 \mathrm{~g} \\
1.0 \mathrm{ml} \text { of } 1.0 \mathrm{M} \text { soln. } \\
10 \mathrm{ml} \text { of } 0.1 \mathrm{M} \text { soln. } \\
5 \mathrm{ml} \text { of } 0.2 \mathrm{M} \text { soln. } \\
0.5 \mathrm{ml} \\
3 \mathrm{mg}\end{array}$ & $\begin{array}{r}49 \mathrm{~mm} \\
49 \mathrm{~mm} \\
. \quad 49 \mathrm{~mm} \\
\end{array}$ & $\begin{array}{c}5 \mathrm{~mm} \\
5 \mathrm{mM} \\
5 \mathrm{mM} \\
0.015 \mu \text { moles } \\
\text { per } \mathrm{cm}^{2} \text { gel } \\
\text { area }\end{array}$ \\
\hline
\end{tabular}

the gel was cold, over-rapid setting of the agarose sometimes prevented the formation of a thin, even layer.

The preparation was left undisturbed until the agar layer was thoroughly set $(10 \mathrm{~min}$.), then, after removing the 2.5 by $2.5 \mathrm{~cm}$ "Perspex" square, it was transferred again to the $37^{\circ}$ incubator. At intervals, the gel was taken to a photographic dark room for inspection under ultra violet light.

The lamp used was a Philips $125 \mathrm{~W} \mathrm{MBW} / \mathrm{U}$ bulb (requiring a choke and capacitor), mounted in a 3-pin ceramic holder which served also as a handle. This was switched on 10 min. before the first inspection, and left on throughout the period of the experiment, supported above the bench by a laboratory clamp, gripping the holder. Shielding was considered unnecessary as the glass envelope was found to be an adequate protection against dangerous short wavelength radiation. For inspection, the electrophoresis tray was placed on a sheet of black paper, and the lamp brought, by hand, close to the surface of the gel. The dark room lights were, of course, switched off during the inspection. To obtain quantitative results, it was necessary to employ standard times of inspection, namely 15, 30,60,100, 150, and $240 \mathrm{~min}$. after application of the agar layer.

The 2.5 by $2.5 \mathrm{~cm}$ "Perspex" square served to exclude the substrate-containing agar layer from one corner of the gel. This area appeared dark because of the absence of $\mathrm{NADH}$ fluorescence and served as a standard against which dark zones resulting from enzymic oxidation of the nucleotide could be gauged. At each inspection, the region between 1.0 and $2.0 \mathrm{~cm}$ on the anode side of the origin slots was carefully scanned for dark spots. The position and shape of "zone II" bands was quite distinctive. Grades $\mathrm{F}$ to $\mathrm{A}$ were allotted according to the inspection at which a distinct zone could first be made out: $-15 \mathrm{~min}$., grade F, approximately $35 \mathrm{U} / \mathrm{l}$ cationic isoenzyme; $30 \mathrm{~min}$., grade E, approximately $19 \mathrm{U} / l ; 60 \mathrm{~min}$., grade $\mathrm{D}, 11 \mathrm{U} / l ; 100 \mathrm{~min}$., grade C, $7 \mathrm{U} / l$; 150 min., grade B, $5 \mathrm{U} / l ; 240$ min., grade A (normal), $3 \mathrm{U} / l$. Incubation was not normally prolonged beyond $240 \mathrm{~min}$., but for grades $\mathrm{F}$ to $\mathrm{B}$ an additional criterion was used - that by the next inspection after allotting a grade the zone should have progressed to become as dark as the standard (NADH-free) area. If this did not occur, the grading was revised to read one lower (e. g. grade D for grade E, etc:). This system of grading, and the approximate activities given above, apply only to zone II, and herice only to the cationic isoenzyme. Clearly, the method must be regarded as only semi-quantitative. The equivalent activities given above for each grade are based on calibration experiments exemplified by figure 1 , and upon evidence that the true normal level is $3 \mathrm{U} / \mathrm{l}$ (see below).

Photographic recording of the patterns (when necessary) was by fluorescent light using $f$ 2.8, Kodak Panatomic $X$ film and a Kodak No. 61 filter over the camera lens (12). The source of exciting light was the MBW/U bulb described above, which was moved to and fro about $25 \mathrm{~cm}$ from the gel surface throughout an exposure period of $2 \mathrm{~min}$.

Separation of macroglobulin - bound enzyme by gel filtration chromatography

The column used, the Sephadex G150, and the procedure in general were as described elsewhere (7). The column was equilibrated with $25 \mathrm{~mm}$ borate buffer, $\mathrm{pH} 8.4$. 


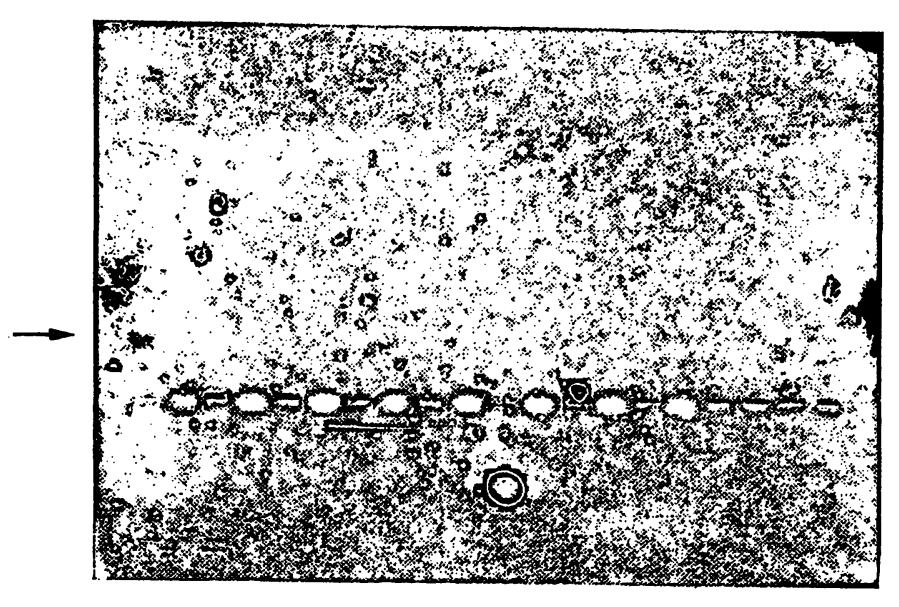

$\boldsymbol{E}$

$30 \mathrm{~min}$
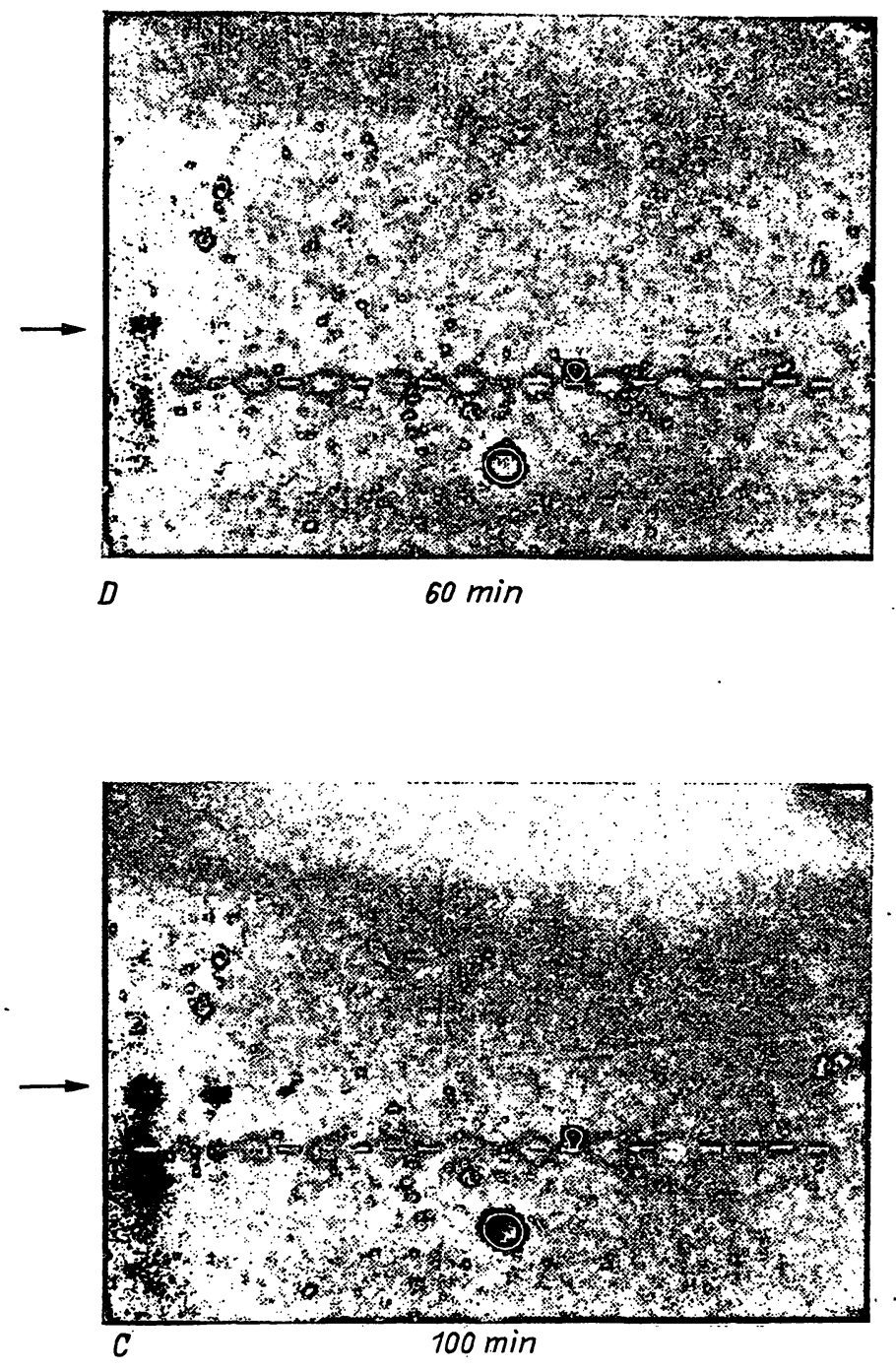

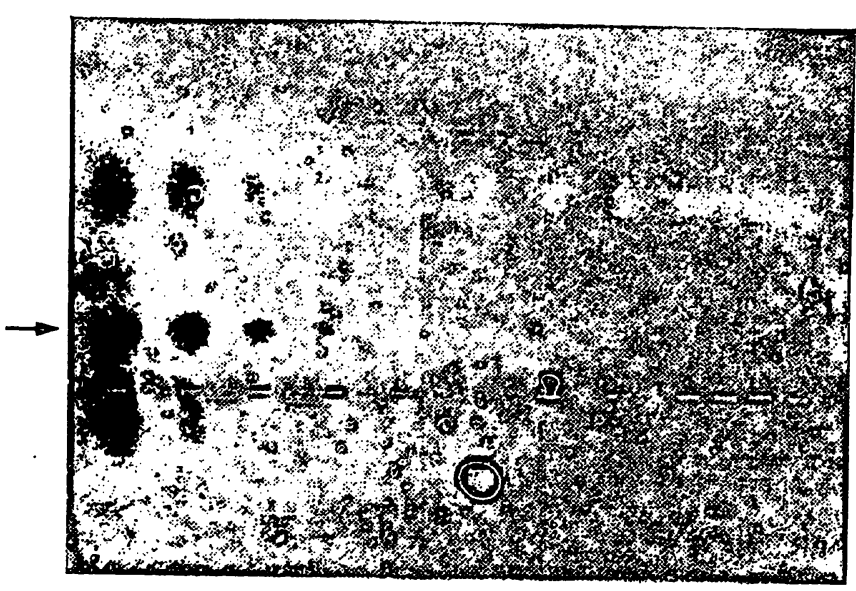

B

$150 \min$

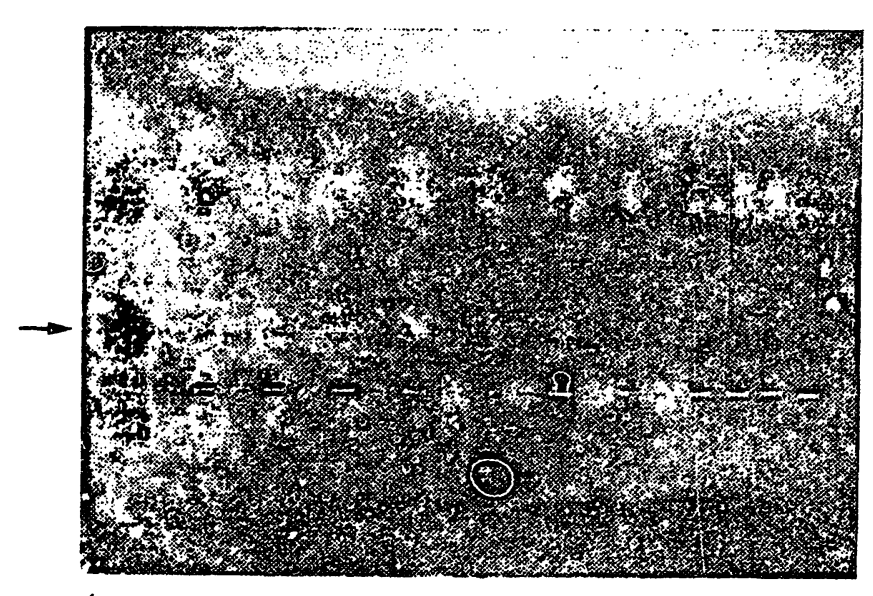

$240 \mathrm{~min}$

Fig. 1

Calibration of the method for semiquantitative assay of cationic aspartate aminotransferase. Successive photographs of a single gel by fluorescent light

Preparation of gel, electrophoresis, and procedure for detection of enzyme activity were as described in the text.

The samples were prepared as follows. To $1.0 \mathrm{ml}$ of normal serum was added a preparation (11) of cationic isoenzyme, containing in $5 \mu l, 100 \mathrm{mU}$ enzyme activity. A portion of this mixture was diluted further.with 2 volumes of normal serum, to give a serum containing approximately $32 \mathrm{U} / l$ added cationic isoenzyme. Using this as the It is assumed that normal serum contains $3 \mathrm{U} / l$ cationic isoenzyme.

\begin{tabular}{|c|c|c|c|}
\hline Track No. & Grade & $\begin{array}{l}\text { Cationic } \\
\text { isoenzyme } \\
\text { added, U/l }\end{array}$ & Total, U/l \\
\hline $\begin{array}{r}1 \\
13 \\
5 \\
7 \\
9 \\
9 \\
11 \\
13 \\
15 \\
17 \\
18 \\
19 \\
20\end{array}$ & $\begin{array}{l}\mathrm{F} \\
\mathrm{E} \\
\mathrm{D} \\
\mathrm{C} \\
\mathrm{B}\end{array}$ & $\begin{array}{l}32 \\
16 \\
8 \\
4 \\
2 \\
0.5 \\
1.0 \\
0.25 \\
= \\
=\end{array}$ & $\begin{array}{c}35 \\
19 \\
11 \\
7 \\
5 \\
3.5 \\
4.0 \\
3.25 \\
\text { Normal serum (J. H. D.) } \\
\text { Normal serum (A. H.) } \\
\text { Normal serum (S. A. S.) } \\
\text { Normal serum (A. W. S.) }\end{array}$ \\
\hline
\end{tabular}

Tracks count from left to right. The gel is arranged anode end uppermost. The time at which each photograph was taken is given in the figure, together with the lowest grade of activity accepted by the

criteria given in the text.
Only zone II activities (indicated by arrow) are considered. The phot zon show somewhat more contrast are considered. The with the naked eye. It will be noted that the sample in track 13 with ining 100 uded cationic ised containing zone II that does normal serum, whereas that in track 11, containing n.5 to difficulty in grading and have been accorded an intermediate grade, A-B. 
$15 \mathrm{ml}$ of normal human serum was dialysed overnight against this buffer, applied to the column $(760 \mathrm{~m} /$ bed volume), eluted with the same buffer at $12 \mathrm{~m} / \mathrm{h}$ and collected as $10 \mathrm{~m} /$ fractions. Fractions 18-28 were combined and concentrated to $3.4 \mathrm{~m} l$ by ultrafiltration.

Collection of blood. Preparation of serum and plasma

Blood was collected by venepuncture, avoiding stasis and turbulent flow, using stainless steel needles and all-glass syringes lubricated with a silicone preparation. Each specimen was divided between two polyvinyl chloride specimen tubes (Stayne Laboratories Ltd), one without anticoagulant and one containing dry heparin. The latter was mixed gently by inversion and immediately centrifuged at $3000 \mathrm{rev} . / \mathrm{min}$. in an M.S.E. "Minor" centrifuge for $20 \mathrm{~min}$. The topmost layer of plasma was removed at once by means of a PASTEUR pipette and stored in a polyvinyl chloride tube until required for use later the same day. The sample without anticoagulant was allowed to clot and separate at room temperature for $2 \mathrm{~h}$, then the serum separated by brief centrifugation.

\section{Results}

The appearance of zone II in normal serum specimens is illustrated in tracks $1 \dot{7}-20$, figure 1 .

In experiments using the same set of normal serum specimens on each of three gels, run and tested simultaneously, it was observed that if either L-aspartate or 2-oxoglutarate were omitted from the detection mixture, none of the enzyme zones appeared. This indicates that all the zones which can be visualized by the present technique, including zone II, are due only to the activity of aspartate aminotransferase.

There was no difference in zone II activity between serum and plasma prepared simultaneously from the same blood samples from normal individuals.

\section{Identification of isoenzyme responsible for zone II}

The serum macroglobulin concentrate (for preparation, see above) was tested by the electrophoretic assay procedure. No activity appeared in the zone I area. The zone II activity was grade $\mathrm{D}-$ equivalent to $2: 5 \mathrm{U} / l$ cationic isoenzyme in the original serum specimen after allowance has been made for the volume reduction by ultrafiltration.

$0.5 \mathrm{~m} l$ aliquots of the serum macroglobulin concentrate were subjected to differential assay by the procedure of Fleisher, PotTer and Wakim (1). The ratio, (Rate at $\mathrm{pH}$ 6.0)/(Rate at $\mathrm{pH}$ 7.4), was found to be 0.405 . Purified preparations of the isoenzymes from human liver (11) were tested at the same time. The ratios obtained were, cationic isoenzyme, 0.36 , anionic isoenzyme, 0.03 .

\section{Normal serum level of cationic isoenzyme.}

Direct assay of the serum macroglobulin concentrate gave $15.2 \mathrm{U} / l$ - equivalent to $3.4 \mathrm{U} / l$ in the original serum specimen. This may be compared with the figure of $2.5 \mathrm{U} / l$ suggested by the electrophoretic assay procedure. Having regard to the potential sources of error in these two determinations, it is suggested that the normal level should be accepted as approximately $3 \mathrm{U} / l$. By the present technique, all normal serum samples are indistinguishable in regard to their zone II activity.

\section{Discussion}

It is shown above that cationic aspartate aminotransferase is a normal constituent of plasma. Although leucocytes contain cationic isoenzyme (15), the activity observed in normal serum originates elsewhere.

Most other workers have been unable to detect the cationic isoenzyme in normal serum $(2,16-20)$, presumably because their methods of assay were insufficiently sensitive.

FLEISHER's group $(2,21)$ injected cationic isoenzyme into dogs, intravenously, and found that it was cleared rapidly and completely. This observation has been used to explain the seeming absence of the isoenzyme from normal serum and its transient appearance in disease $(2,16,17)$. Plainly it is necessary to reinjestigate the plasma levels in disease, using a more sensitive method of assay than heretofore. Clinical results with the present method will be reported separately (22).

NotARBartolo and coworkers (23) have recently reported finding $3 \pm 1$ (mean \pm standard deviation) $\mathrm{U} / \mathrm{l}$ cationic isoenzyme in normal serum - in agreement with the present results. It is not clear, however, how the Italian workers excluded interference from anionic isoenzyme. Rotzsch (24) has employed a technique involving cellulose acetate electrophoresis and elution prior to assay by the method of REITMAN and FrANKEL (25). He reported finding cationic isoenzyme activity equivalent to $7 \mathrm{U} / \mathrm{l}$ in normal serum. If an appropriate allowance is made for the serious underestimation of cationic isoenzyme by the REITMAN and FRANKEL method $(5,12)$, the result would be much higher still, but even as it stands the figure is so high as to cast doubt on the specificity of the overall procedure. According to the present procedure, all normal sera are indistinguishable. It is, of course, improbable that the normal level is so little variable as this would suggest. If small variations about the norm are clinically significant, a very precise and specific quantitative assay will be required. This has not yet been achieved.

There is a possibility of making this or related methods truly quantitative. One might arrange for fluorescence scanning of the finished gel. Alternatively one might cut out the "slow $\alpha_{2}$ "-zone and assay the activity in this region (12).

The present procedure can be used to measure cationic isoenzyme otherwise than in serum, if a source of $\alpha_{2}$-macroglobulin is provided.

\section{Acknowledgements}

This work is part of that submitted to the University of London as a Thesis for the degree of M. D. The author thanks Professor A. L. LATNER for his encouragement and for his help in preparing the manuscript. 


\title{
References
}

1. Fleishier, G. A., C. S. Potter and K. G. Whkim, Proc. Soc. exp. Biol. Med., 103, 229 (1960). - 2. Fleisher, G. A. and K. G. Wakim, Proc. Soc. exp. Biol. Med. 106, 283 (1961). - 3. Rosenthat, O., S. K. Thind and N. Conger, Abstr. Amer. chem. Soc., 138 th Meeting, New York, 10C, (1960). - 4. Borst, P. and E. M. Peeters, Biochim. biophysica Acta (Amsterdam) 54, 188 (1961). -5. BoYd, J. W., Biochem. J., 81, 434 (1961). - 6. BoYDE, T. R. C. and A. L. LATNER, Biochem. J., 82, 51P (1962). - 7. BoYDE, T. R.C. in preparation. - 8. Martinez-Carrion, M., F. Riva, C. Turano and P. Faselia, Biochem. Biophys. Res. Comm. 20, 206 (1965). - 9. Martinez-Carrion, M., C. Turano, M. Chiancore, F. Bossa, A. Giartosio, F. Riva and P. Fasella, J. biol. Chemistry 242, 2397 (1967). - 10. Martinez-Carrion, M. and D. Tiemier, Biochemistry (USA) 6, 1715 (1967). - 11. Boyde, T. R. C., Biochem. J., 106, 581 (1968). - 12. Boyde, T. R. C., M. D. Thesrs, University of London, 1967. - 13. Boxde, T. R. C. and I. F. PrYMe, Clin. Chim. Acta (Amsterdam) 21, 9 (1968). -
14. Karmen, A., J. Clin. Invest., 34, 131 (1955). - 15. Ideo, G., P. M. Mannucci, E. MunN, G. Funelir and N. Dioguardi, Boll. Soc. ital. biol. sper., 41, 942, 954 (1965). - 16. Massarat, S. and N. LaNG, Klin. Wschr., 43,602 (1965). - 17. Schwartz, M. K. and O. Bodansky, Amer. J. Med.40,231 (1966).-18. VilLA, L., N. Dioguardi and A.Agoston, Klin. Wschr. 45, 44 (1967). - 19. Neumieister, E., P. Otro, E. Schmidt and F. W. Schmidt, Med. Welt, 1497 (1965). - 20. Romer, W. C. and S. J. La Mancusa, Clin. Chem. (New York) 11, 131 (1965). - 21. FleIsher, G. A. and K. G. WAKIM, J. Laborat. clin. Med. (S. Louis) 61, 98 (1963). - 22. BoxDE, T. R. C., Enzymol. biol. clin., in press. - 23. Notarbartolo, A., F. Giglio, S. LeMoli, G. Mrgneco and L. Pagliaro, Boll. Soc. ital. biol. sper., 42, 328 (1966). - 24. RotzsCH, W. and K. W. Wenzer, Acta biol. med. german., 17, 561 (1966). 25. Retrman, S. and S. Frankel, Amer. J. clin. Path., 28,56 (1957).
T. R. C. Boyde, M. D.

Dept. Clin. Biochem.

Royal Victoria Infirmary

Newcastle upon Tyne/England

\section{Untersuchungen über das Schicksal von Dextran im Organismus von Meerschweinchen}

\author{
Vón K. H. Ebert, G. Schenk ${ }^{1}$ ) und R. Scholz ${ }^{2}$ ) \\ Institut für Technische Chemie der Technischen Hocbscbule München
}

(Eingegangen am 7. Mai 1968)

Nach einmaliger Injektion von tritiierten Dextranfraktionen mit unterschiedlichen, genau definierten Molekulargewichten, wurde an Meerschweinchen die Verweildauer des Dextrans im Blut, seine Ausscheidung, Metabolisierung und Retention in den Geweben untersucht. Nahezu $100 \%$ der injizierten Tritiumaktivitäten konnten im Blut, in den verschiedenen Organen und in den Ausscheidungsprodukten wiedergefunden werden. Die Verweildauer im Blut und die Ausscheidung über Nieren und Darm zeigen eine hohe Abhängigkeit vom Molekulargewicht des injizierten Dextrans. Eine Ausscheidungsschwelle scheint in den Nieren für Molekulargewichte über $50000 \mathrm{zu}$ bestehen. Die Bildung von Tritiumwasser bestätigt, daß die Dextrane abgebaut und in den intermediären Stoffwechsel eingeschleust werden. Diese Abbaureaktionen zeigen eine molekulargewichtsabhängige Induktionsperiode von ein bis drei Tagen. Niedermolekulare Fraktionen werden bedeutend schneller umgesetzt als höhermolekulare. Dextran wird in den meisten Organen retiniert, wobei hinsichtlich des Ausmaßes dieser Retention folgende Reihenfolge aufgestellt werden kann: Milz, Haut, Lunge, Leber, Niere, Fettgewebe, Skelettmuskulatur. Im Gehirn sind nur Spuren nachweisbar. Mit Ausnahme der Milz ist in den meisten Organen die Dextranretention nur angedeutet molekulargewichtsabhängig. Die Verweildauer der Dextrane im Blut wird vorwiegend von der Ausscheidung über die Nieren bestimmt, Metabolisierung oder Retention in den Geweben haben dagegen keinen wesentlichen Einfluß. Das Verhalten der Milz zeigt jedoch, daß dem reticuloendothelialen System eine bedeutende Rolle bei der Reinigung des Blutes von höhermolekularen Dextranen zukommt.

\section{Studies on the fate of injected dextran in the guinea pig}

Guinea pigs were given single injections of tritiated dextran fractions of different and precisely known molecular weights. The persistence of dextran in the blood, its excretion, metabolism and retention in the tissues were studied. Practically $100 \%$ of the injected tritium activity was found in the blood, various organs and excretory products. The persistence of the dextran in the blood and its excretion via the kidneys and intestine showed a marked dependence on the molecular weight. There appears to be an excretory threshold in the kidneys for molecular weights above 50000. The appearance of tritium water showed that the dextrans are degraded and thereby become involved in intermediary metabolism. These degradation reactions are subject to an induction period of one to three days, depending on the molecular weight of the dextran. Low molecular weight fractions are degraded significantly more rapidly than high molecular weight fractions. Dextran is retained by most organs to an extent represented by the following order: spleen, skin, lungs, liver, kidneys, adipose tissue, skeletal muscle, and only a trace in the brain. With the exception of the spleen, the retention of dextran in most organs is only slightly affected by molecular weight. The persistence of dextrans in the blood is determined chiefly by the excretion via the kidneys, and the metabolism or retention in the tissues have essentially no effect. The behaviour of the spleen shows, however, that the reticuloendothelial system plays a significant part in the purification of the blood by the removal of high molecular weight dextrans.

1) derzeitige Adresse: Knoll AG, Chemische Fabriken, 67 Ludwigshafen a. Rh.

2) z. Z. Johnson Research Foundation, School of Medicine, University of Pennsylvania, Philadelphia/USA. 